\title{
Complement fixing antibody responses to virus infection in children with acute lymphoblastic leukaemia
}

\author{
AW CRAFT, MM REID, J MCQUILLIN, AND PS GARDNER \\ From the Departments of Child Health, Haematology, and Virology, Royal Victoria Infirmary, \\ Newcastle upon Tyne NE1 4LP, UK
}

SUMMARY Thirty children with acute lymphoblastic leukaemia (ALL) were studied and had a virus isolated. Only $50 \%$ produced a significant rise in complement fixing (CF) antibody titre compared to $100 \%$ of normal children. The failure to produce antibodies was unpredictable. CF antibodies are not a reliable guide to virus infections in children with ALL.

Humoral immune responses are of major diagnostic importance in virus infections. ${ }^{1}$ In children with leukaemia, virus infections are being increasingly recognised as a cause of illness and death. ${ }^{23}$ Several children with acute lymphoblastic leukaemia (ALL) in Newcastle upon Tyne did not develop the usual antibody rise in response to a virus infection. ${ }^{3}$ In order to clarify this problem we have surveyed a larger group of children with ALL from whom a virus was isolated and from whom paired sera were taken for antibody determination.

\section{Patients and methods}

From 1974 to 1978 children with ALL attending either of the two major hospitals in Newcastle upon Tyne were investigated virologically whenever a respiratory virus infection was suspected. A diagnosis of a virus infection was made either by the fluorescent antibody technique (FAT) or by culture. ${ }^{4}$ All of the viruses were identified by both the FAT and by culture except for adenovirus and cytomegalovirus, which were only cultured. Whenever possible, blood was taken at the start of the illness and during the convalescent period, and the titre of complement fixing antibody was determined by the method of Bradstreet and Taylor. ${ }^{5}$ Clinical details of the illness and the leucocyte count were also recorded.

\section{CONTROLS}

The control group consisted of 33 patients who had been admitted to the same hospitals with a suspected virus infection. Their ages ranged from 1 to 17 years

Received for publication 30 January 1980 (mean 6.1, SD $5 \cdot 3$ years). A virus was identified from each child, either by FAT or by culture, and paired sera were taken during the acute and convalescent phases of the illness. None had leukaemia or was on immunosuppressive treatment.

\section{Results}

Paired sera were available for 30 virus isolations from children with ALL. There were 14 boys and 13 girls and their ages ranged from 2 to 13 years (mean 5.8, SD $3 \cdot 1$ years). Viruses were isolated from three girls on each of two separate occasions, and one child had an illness during which influenza $\mathrm{A}$ and respiratory syncytial virus were both isolated. From five other children another virus was isolated at the same time as that for which the antibody titres were measured (3 H-strain rhinoviruses, 1 echovirus type 3 , and 1 herpesvirus hominis). The titres of antibody, in both acute and convalescent phases, to the viruses isolated are shown in the Figure. Comparison is made with the normal children, all of whom showed at least a fourfold antibody rise or had an initial antibody titre of at least $1 / 128$. Fifteen of the children with ALL demonstrated a fourfold rise or more to the virus infection, and 15 did not respond. There was no difference in the sex ratio or in the age of those who responded compared to the non-responders. The severity of the clinical illness and the current state of the children are shown in the Table. There is no difference between the two groups. The mean total white cell count and lymphocyte count at the time of diagnosis of the infection was 3.9 $(1.2) \times 10^{9} / 1$ in the responding and $4.0(1.3) \times 10^{9} / 1$ in the non-responding groups. There was no 735 


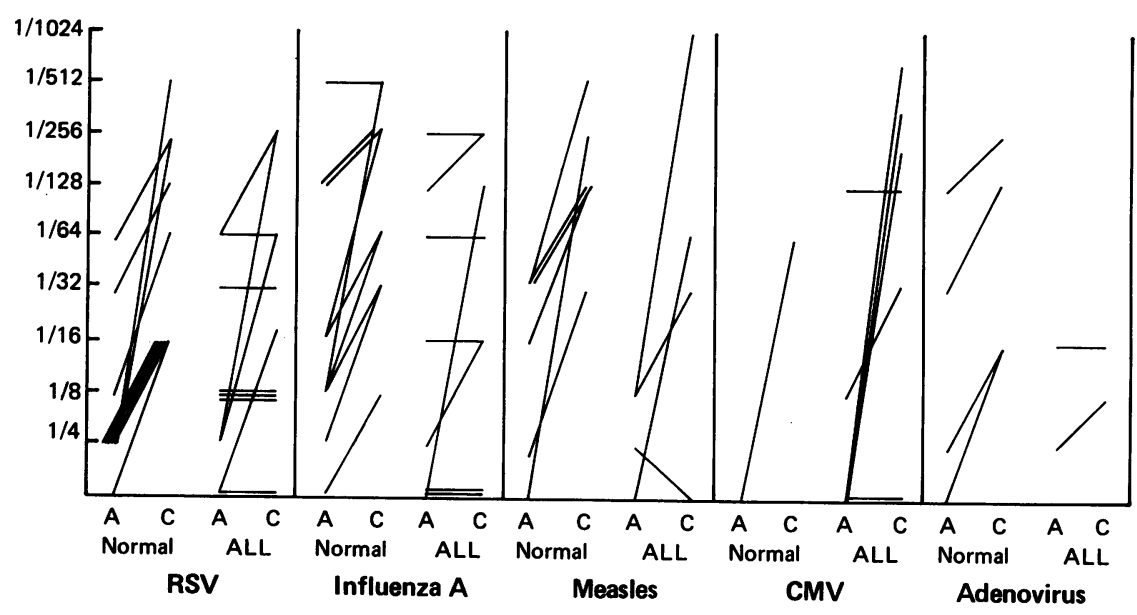

Titre of complement fixing antibody to $R S V$, influenza $A$, measles, cytomegalovirus, and adenovirus in children with leukaemia and in normal children.

$A=$ Acute

$C=$ Convalescent

Present state and severity of illness in children with $A L L$, according to the presence or absence of CFT antibody response to a virus infection

\begin{tabular}{|c|c|c|}
\hline & CFT rise & No CFT rise \\
\hline \multicolumn{3}{|l|}{ Present state } \\
\hline Alive and well & 8 & 8 \\
\hline Relapse & - & 1 \\
\hline Dead & 6 & 4 \\
\hline \multicolumn{3}{|l|}{ Severity of illness } \\
\hline Asymptomatic & 1 & 3 \\
\hline Minor symptoms & 6 & 6 \\
\hline Serious illness & 4 & 3 \\
\hline Life threatening & 3 & 2 \\
\hline Associated with death & 1 & 1 \\
\hline
\end{tabular}

difference in the mean length of time between diagnosis of the leukaemia and of the virus infection in the two groups, and there was no particular period of treatment during which they were unlikely to respond. Three of the children who had other viruses isolated simultaneously produced an antibody rise and three did not.

\section{Discussion}

It is a widely held belief that a rise in complement fixing antibody titre is a satisfactory method of diagnosing a virus infection when methods for either rapid virus diagnosis or viral culture are not readily available. The present data confirm our original impression that in children with ALL reliance on a rise in antibody titre will result in many virus infections being missed.

This failure to produce humoral antibodies may result in increased severity of illness in some children with leukaemia and may also account for the pro- longed period for which viruses are sometimes excreted in this condition. ${ }^{3}$ The role of complement fixing antibodies in the host defence against virus infections is not clear. It may be that they do not play a major role and simply reflect the production of other, perhaps more important, local antibodies which can coat the virus and halt its replication. ${ }^{6}$ The reason why half of the children with ALL did not produce antibodies is not clear. It does not appear to be related to sex, time from diagnosis, a particular phase of chemotherapy, age, white count, or severity of illness and therefore appears to be entirely unpredictable.

Borella and Webster ${ }^{7}$ have reported some impairment of the immune response to virus infections in children with leukaemia. Attempts at immunisation with live virus vaccine in children with leukaemia have shown variable results. Bosu et al. ${ }^{8}$ demonstrated a uniform failure of IgM response to polio vaccine administration, which persisted for up to six months after the child had stopped immunosuppressive treatment. Gross et al., using a haemagglutination inhibition (HAI) technique, found that $37 \%$ of children on immunosuppressive therapy for malignant disease responded to influenza vaccination compared to $92 \%$ who were not on treatment. ${ }^{9}$ They, too, found no correlation between the immune response and the peripheral white blood cell count. On the other hand, Izawa et al. ${ }^{10}$ and Ozaki et al. ${ }^{11}$ have shown that live varicella vaccine usually produces a satisfactory CF and neutralising antibody rise in children with leukaemia, and Sumaya et al..$^{12}$ and Smithson et al. ${ }^{13}$ have reported no difference in satisfactory immunisation rates against influenza viruses in children with malignant disease and in 
normals. The different conclusions reached in these various studies may result from the different techniques used to detect antibodies (HAI, CFT, neutralisation) and to the varied state of immunosuppression of the children, some being on and others off treatment.

Children with ALL are more susceptible to multiple virus infections occurring simultaneously than are normal children. ${ }^{14}$

The presence of two viruses might inhibit the CF response to one, as may occur when two live virus vaccines are given together, ${ }^{15}$ although, more recently, satisfactory immunisation rates have been reported with up to four vaccines given at the same time. ${ }^{16}$

It is possible that more sensitive tests for measuring antibody responses, such as immunofluorescence, ELISA, or radioimmunoassay, might detect a response in those children who do not produce a CFT rise. At present neutralisation tests and, where appropriate, the HAI are the best measures of the immune status of the patient to a particular virus infection. However, the role of cell-mediated immunity also needs to be considered.

We conclude that humoral complement fixing antibody responses are not a reliable guide to virus infections in children with ALL and that the more general acceptance of this will lead to a greater awareness of the importance of using culture and immunofluorescence techniques in addition to $C F$ tests for the diagnosis of virus infections in children. It is only by the use of all the available diagnostic tools for the recognition of viruses and a thorough study of all the immune responses, employing the most advanced techniques, that the true significance of virus infections in the life and death of children with leukaemia will be understood.

We thank the Tyneside Leukaemia Research Association for financial support and Professor W Walker and Dr TC Noble for allowing us to study patients under their care.

\section{References}

${ }^{1}$ Jawetz E, Melnick JL, Adelberg EA. Review of Medical
Microbiology, 13th ed. Los Altos, California: Lange, 1978.

2 Craft AW, Reid MM, Bruce E, Kernahan J, Gardner PS. Role of infection in the death of children with acute lymphoblastic leukaemia. Arch Dis Child 1977;52:752-7.

3 Craft AW, Reid MM, Gardner PS, et al. Virus infections in children with acute lymphoblastic leukaemia. Arch Dis Child 1979;54:755-9.

4 Gardner PS, McQuillin J. Rapid Virus Diagnosis: Application of Immunofluorescence. London: Butterworths, 1974.

5 Bradstreet CMP, Taylor CED. Technique of complement fixation test applicable to the diagnosis of virus diseases. Mth Bull MOH Lab Serv 1962;21 :96-104.

- Gardner PS, McQuillin J. The coating of respiratory syncytial virus-infected cells in the respiratory tract by immunoglobulins. J Med Virol 1978;2:165-73.

7 Borella L, Webster RG. The Immunosuppressive effects of long term combination chemotherapy in children with acute leukemia in remission. Cancer Res 1971;31:420:6.

${ }^{8}$ Bosu SK, Ciudad H, Sinks LF, Ogra PI. Antibody response to poliovirus immunization in childhood leukemia. Med Pediatr Oncol 1975;1:217-25.

- Gross PA, Lee H, Wolff JA, Hall CB, Minnefore AB, Lazicki ME. Influenza immunization in immunosuppressed children. J Pediatr 1978;92:30-5.

${ }^{10}$ Izawa $T$, Ihara $T$, Hattori $A$, et al. Application of live varicella vaccine in children with acute leukemia or other malignant diseases. Pediatrics 1977;60:805-9.

11 Ozaki T, Nagayoshi S, Morishima T, et al. Use of a live varicella vaccine for acute leukemic children shortly after exposure in a childrens ward. Biken $J$ 1978;21: 69-72.

12 Sumaya CV, Williams TE, Brunell PA. Bivalent influenza vaccine in children with cancer. Infect Dis 1977;136: Suppl.656-60.

${ }^{13}$ Smithson WA, Siem RA, Ritts RE, Jr, et al. Response to influenza virus vaccine in children receiving chemotherapy for malignancy. J Pediatr 1978;93:632-4.

14 Bruce E, Reid MM, Craft AW, Kernahan J, Gardner PS. Multiple virus isolations in children with acute lymphoblastic leukaemia. J Infect 1979;1:243-8.

15 Advisory Committee on Immunisation Practices: Recommendations. Morbid Mortal Wkly Rep 1969;18:Suppl.11.

${ }^{16}$ Karchmer AW, Friedman JP, Casey HL, et al. Simultaneous administration of live virus vaccines. Am J Dis Child $1971 ; 121: 382-8$.

Requests for reprints to: Dr AW Craft, Department of Child Health, Royal Victoria Infirmary, Newcastle upon Tyne NE1 4LP, UK. 